\title{
PEMANFAATAN LIMBAH KRUSTASEA DALAM PEMBUATAN GLUKOSAMIN HIDROKLORIDA DENGAN METODE AUTOKLAF
}

\author{
UTILIZATION OF CRUSTASEAN SHELL WASTE FOR PRODUCTION OF \\ GLUCOSAMINE HYDROCHLORIDE BY USING \\ AUTOCLAVING METHOD
}

Pipih Suptijah ${ }^{1}$, Bustami Ibrahim ${ }^{1}$, Ernawati $^{1}$

${ }^{1}$ Departemen Teknologi Hasil Perairan

Fakultas Perikanan dan Kelautan, Institut Pertanian Bogor

Korespondensi : suptijah@yahoo.com

\begin{abstract}
Utilization of crustacean shell waste to produce chitosan can continue by derivatisation to produced glucosamine. $\mathrm{GlcN} \mathrm{HCl}$ is one of the nutraceuticals product widely consumed for reducing osteoarthritis symptoms. The minimum local production of glucosamine itself encourages a proper glucosamine production technology. The purpose of this study was to obtain optimum production technique of glucosamine hydrochloride. Production of glucosamine hydrochloride used presured hydrolysis method by pressured treatment (autoclaving), heating time (hours), and acid $(\% \mathrm{v} / \mathrm{v})$. Characteristic of glucosamine hydrochloride was determined for solubility parameters, appearance, yields, value loss on drying (LOD), the melting point temperature and FTIR absorption. The quality standard of hydrolyzed glucosamine refers to the standard of United State Pharmacopeia. The results showed that the optimum techniques of glucosamine hydrochloride production were using $\mathrm{HCl}(8 \%)(\mathrm{v} / \mathrm{v})$ and $1 \mathrm{~atm}$ pressure for 1 hour. Hydrolyzed glucosamine hydrochloride was completely dissolved in water, yellowish-white powder appearance with $(69.80 \%)$ of yield, LOD value was $0.92 \%$, and the melting point temperature was $190-193{ }^{\circ} \mathrm{C}$. FTIR spectrum showed functional group of $\mathrm{OH}$ at $300-3263 \mathrm{~cm}^{-1}$ and amida group at $1566 \mathrm{~cm}^{-1}$, wassimilar absorption band patterns with hydrolyzed glucosamine hydrochloride of standard.
\end{abstract}

Keywords: glucosamine hydrochloride, hydrolysis, osteoarthritis, pressured hydrolysis

\begin{abstract}
ABSTRAK
Limbah industri pengolahan udang dan rajungan yang mencapai lebih dari 50\% berat awalnya, dapat dimanfaatkan sebagai bahan baku pembuatan kitosan. Kitosan sebagai polimer alami yang banyak manfaatnya diberbagai bidang, juga dapat diderivatisasi menjadi glukosamin. $\mathrm{GlcN} \mathrm{HCl} \mathrm{merupakan} \mathrm{salah} \mathrm{satu} \mathrm{suplemen} \mathrm{alami} \mathrm{yang} \mathrm{banyak} \mathrm{dikonsumsi}$ masyarakat dunia saat ini terutama dalam fungsinya mengatasi gejala penyakit osteoarthritis. Rendahnya produksi glukosamin dalam negeri menuntut adanya suatu teknologi produksi glukosamin yang tepat. Tujuan penelitian ini adalah untuk memperoleh teknik produksi glukosamin hidroklorida yang optimum. Metode penelitian yang digunakan adalah metode hidrolisis kimiawi dengan variabel bebas yakni perlakuan hidrolisis bertekanan (autoclaving), waktu pemanasan (jam), dan konsentrasi asam (\% v/v). Karakteristik glukosamin hidroklorida terbaik dilihat dari parameter kelarutan, penampakan, rendemen, nilai loss on drying (LoD), titik leleh, dan serapan gugus fungsi FTIR. Standar mutu glukosamin hidrolisis mengacu pada standar United State Pharmacopeia. Teknik hidrolisis glukosamin terbaik diperoleh pada penggunaan $\mathrm{HCl}(8 \%)(\mathrm{v} / \mathrm{v})$ dengan tekanan maksimum $1 \mathrm{~atm}$ selama $1 \mathrm{jam}$. Glukosamin hidroklorida hasil hidrolisis memiliki karakteristik yakni larut sempurna dalam air, berbentuk serbuk berwarna puth kekuningan, memiliki LoD $(0,92 \%)$, titik leleh $190-193{ }^{\circ} \mathrm{C}$, dan rendemen $(69.80 \%)$. Spektrum FTIR menunjukkan pola pita serapan $\mathrm{OH}$ pada bilangan gelombang 3000-3263 $\mathrm{cm}^{-1}$ dan pita serapan amida pada bilangan gelombang $1566 \mathrm{~cm}^{-1}$ yang sesuai dengan GlcN HCl dengan standar.
\end{abstract}

Kata kunci: glukosamin hidroklorida, hidrolisis, osteoarthritis, hidrolisis bertekanan 


\section{PENDAHULUAN}

Limbah industri krustasea (udang dan rajungan) dapat mencapai 50\% lebih dari total bobot awalnya. Limbah tersebut sudah dimanfaatkan sebagai bahan tambahan pada pakan ternak, tetapi apabila tidak ditangani dengan bijak akan menimbulkan pencemaran lingkungan. Suatu alternatif yang ramah lingkungan adalah mengolah limbah menjadi kitosan yang banyak manfaatnya diberbagai bidang, serta melanjutkan ke proses derivatisasi menjadi glukosamin, yang akhir akhir ini sedang trendi dalam mengantisipasi osteoarthritis. Osteoarthritis (OA) merupakan salah satu penyakit radang sendi yang ditandai dengan kerusakan progresif pada tulang rawan yang diiringi dengan perubahan tulang subkondral (Zamli \& Sharif 2011). Setidaknya sekitar 68\% lansia di Amerika berusia di atas 55 tahun telah terbukti memiliki riwayat OA dengan 85\% diantaranya berusia 75 tahun. Jumlah ini diperkirakan akan terus meningkat setiap tahunnya (Wang et al. 2007).

Glukosamin merupakan salah satu senyawa gula amino yang ditemukan secara luas pada tulang rawan dan memiliki peranan yang sangat penting untuk kesehatan dan kelenturan sendi (EFSA 2009). Pentingnya glukosamin terhadap kesehatan sendi diantaranya konsumsi glukosamin hidroklorida dan atau glukosamin sulfat terhadap pasien penderita OA (tingkat sedang) berpengaruh nyata terhadap pengurangan rasa nyeri pada sendi (Kulkarni et al. 2012), mampu mengurangi nyeri sendi pada pasien yang memiliki penyakit osteoarthritis berikut mekanismenya seperti membantu menghilangkan rasa nyeri sendi (Usha \& Naidu 2004), serta membantu perbaikan sendi dan membantu untuk melindungi kerusakan tulang rawan (Clegg et al. 2006 $\&$ Cibere et al. 2004). White \& Stegemann (2001) menguraikan alas an meningkatnya konsumsi glukosamin diantaranya karena persepsi masyarakat mengenai pemakaian produk alami yang aman.

Metode pembuatan glukosamin dengan asam pekat baik secara pemanasan langsung ataupun dengan autoklaf, menghasilkan rendemen dan kualitas yang belum memenuhi syarat diantaranya warna yang masih kecoklatan, titik leleh masih di bawah standar, kelarutan belum sempurna serta spectrum Infra merah yang belum bersih masih banyak noise (Afridiana 2011 \& Rismawan 2012)

Pada penelitian ini dilakukan pengembangan metode dari penelitian terdahulu untuk memperoleh kondisi optimum sintesis glukosamin dari kitosan, melalui modifikasi metode hidrolisis bertekanan menggunakan autoklaf dalam suasana asam yang lebih rendah konsentrasi, sehingga lebih aman, sederhana dan efisien. Kondisi optimum glukosamin akan ditentukan dari kelarutan, penampakan, warna, titik leleh (melting point temperature), pita serapan infra merah (uji FTIR), dan nilai rendemen glukosamin. Tujuan penelitian ini adalah memperoleh teknik produksi glukosamin hidroklorida yang praktis dan efisien melalui penggunaan teknologi hidrolisis bertekanan sehingga diperoleh produk glukosamin dengan rendemen dan karakter mutu yang baik. Metode pembuatan glukosamin dengan metode hidrolisis bertekanan dengan autoklaf dalam asam encer, diharapkan dapat lebih aman, dengan hasil berkualitas standar, efisien dan siap diuji in vivo.

\section{METODE PENELITIAN}

Bahan yang digunakan adalah kitosan dari PT Biotech Surindo Cirebon, HCl 12 N (teknis), Isoprophyl Alcohol/ IPA (teknis), dan akuades. Alat-alat yang digunakan adalah labu Erlenmeyer $250 \mathrm{~mL}$, autoklaf bertekanan 2 atm, pH meter, FTIR (Perkin Elmer Spektrum One), pemanas listrik titik leleh (MelTemp), gelas piala $100 \mathrm{~mL}$, pipet morr $10 \mathrm{~mL}$, gelas ukur $50 \mathrm{~mL}$, oven (DV41), kertas $\mathrm{pH}$, kertas saring, dan timbangan digital (Sartorius TE 1502 S).

\section{Prosedur penelitian}

Proses pembuatan glukosamin dilakukan dengan metode hidrolisis bertekanan menggunakan autoklaf dengan perlakuan variasi konsentrasi asam klorida, tekanan dan waktu proses. Metode yang digunakan merupakan pengembangan metode penelitian Rismawan (2012). Proses diawali dengan penimbangan kitosan kemudian dimasukkan ke dalam larutan $\mathrm{HCl}$ dengan rasio sampel: $\mathrm{HCl}=1: 9$. Perlakuan konsentrasi $\mathrm{HCl} 0-22 \%$ (v/v) dengan interval konsentrasi $2 \%$. Waktu pemanasan yang diberikan adalah 30, 60, 90, dan 120 menit pada tekanan vakum 0.50 dan 1 atm. 


\section{HASIL DAN PEMBAHASAN}

\section{Metode hidrolisis bertekanan dengan autoklaf}

Produksi glukosamin dengan metode hidrolisis bertekanan dalam autoklaf, pada dasarnya merupakan sistem kerja yang menggabungkan fungsi tekanan dan pereaksi asam yang menimbulkan reaksi hidrolisis yang lebih aman. Tekanan berperan penting dalam pemotongan ikatan polimer menjadi unit-unit yang lebih kecil. Berdasarkan Hukum Rault bahwa fraksi mol suatu campuran mempunyai tekanan uap tertentu, peningkatan fraksi campuran akan meningkatkan tekanan uap campuran sehingga meningkatkan pergerakan molekul yang menimbulkan peningkatan reaksi. Mustamin dan Manjang (2010) menyatakan bahwa perbedaan tekanan parsial antara bahan dan atmosfir/lingkungan memungkinkan penetrasi larutan ke dalam bahan/polimer, ditunjang oleh Kralovec dan Barrow (2008) yang menyatakan bahwa kadar asam yang rendah menyebabkan terjadinya hidrolisis yang tidak sempurna, oleh karena itu penggunaan asam encer perlu dimodifikasi dengan tekanan agar hidrolisis menjadi sempurna.

Mekanisme kinerja asam dan tekanan terhadap sampel dapat dijelaskan sebagai berikut: bahwa asam klorida dibantu dengan tekanan berperan dalam hidrolisis ikatan polimer kitosan (2000-3000 monomer) menjadi unit unit yang lebih kecil dan ionisasi gugus amin $-\mathrm{NH}_{2}$ sehingga gugus amin dapat berikatan dengan gugus klorida membentuk glukosamin hidroklorida. Glukosamin hidroklorida dapat larut dalam air karena adanya gugus - $\mathrm{OH}$ dan $\mathrm{NH}_{3} \mathrm{Cl}$ pada unit unit polimer yang sudah menjadi lebih kecil, jadi fungsi tekanan pada autoklaf membantu proses pemotongan rantai polimer kitosan menjadi lebih pendek yang menyebabkan glukosamin larut dalam air.

\section{Pembuatan glukosamin hidroklorida dari kitosan}

Peubah yang diragamkan pada penelitian meliputi konsentrasi asam, yang berkisar antara $0-22 \%(\mathrm{v} / \mathrm{v})$ dengan interval $(2 \%)$, disertai tekanan 1 atm dan waktu pemanasan 1 jam. Karakteristik glukosamin yang dihasilkan disajikan pada Tabel 1 . Semua sampel (kecuali kontrol) dari setiap perlakuan bersifat larut sempurna dalam air. Kelarutan ini merupakan indikasi awal yang menunjukkan bahwa sampel kitosan telah terhidrolisis menjadi glukosamin hidroklorida, dari pengamatan langsung secara visual glukosamin yang palig baik kelarutannya dengan warna paling cerah adalah perlakuan konsentrasi asam 8\%. Rismawan (2012) telah membuat glukosamin hidroklorida dari kitosan dengan perlakuan terbaik yakni penggunaan $\mathrm{HCl} 22 \%$ (v/v) dan waktu pemanasan selama 2 jam pada autoklaf bertekanan $1 \mathrm{~atm}$.

Parameter yang dilihat selanjutnya setelah kelarutan ialah warna, penampakan derajat putih, konsentrasi $\mathrm{HCl}$, dan nilai rendemen glukosamin.Perlakuan hidrolisis dengan asam 8\% ditetapkan sebagai perlakuan terbaik glukosamin yang kemudian dikarakterisasi lebih lanjut. Sampel terbaik dilengkapi uji lanjutan meliputi uji pengurangan bobot loss on drying LoD, uji titik leleh, dan uji serapan FTIR.

\section{Kelarutan glukosamin hidroklorida (GlcN HCl)}

Uji kelarutan glukosamin hidroklorida dilakukan menggunakan air bersuhu 27 ${ }^{\circ} \mathrm{C}$. Pada uji lanjutan, kelarutan dilakukan kembali menggunakan air bersuhu $20{ }^{\circ} \mathrm{C}$. Semakin tinggi suhu pelarut yang digunakan maka kelarutan zat akan terjadi lebih cepat. Kelarutan cenderung lambat dalam pelarut bersuhu rendah. Suatu zat yang larut dengan mudah pada pelarut bersuhu rendah mengindikasikan bahwa zat terlarut memiliki tingkat kelarutan yang baik.

Kitosan telah kehilangan gugus asetilnya karena adanya mekanisme pemotongan (deasetilasi) oleh basa kuat (Azhar et al. 2010). Tekanan pada autoklaf tidak lagi memutus gugus asetil pada sampel melainkan hanya memotong polimer kitosan menjadi unit yang lebih kecil sehingga ion $\mathrm{Cl}^{-}$dari $\mathrm{HCl}$ lebih mudah berikatan dengan dengan gugus amin kitosan membentuk $\mathrm{NH}_{3} \mathrm{Cl}$. Adanya gugus hidroksil $\mathrm{O}-\mathrm{H}$ dan gugus $\mathrm{NH}_{3} \mathrm{Cl}$ ini menyebabkan glukosamin hidroklorida bersifat larut dalam air.

Standar United States Pharmacopeia (USP) menyatakan bahwa penampakan glukosamin secara visual adalah putih. Ketika glukosamin dilarutkan dalam air, larutan akan cenderung jernih dan tidak berwarna. Berbeda dengan warna glukosamin yang dihasilkan (Gambar 1). Glukosamin hasil hidrolisis berwarna jernih kekuningan setelah dilarutkan. Hal ini diduga karena warna asal sampel 
(kitosan) yang masih mengandung sedikit pigmen atau sedikit protein pengotor, tetapi sesungguhnya hampir semua pengotor dan produk sampingan dari proses pembuatan glukosamin dapat dibersihkan dengan pencucian yang intensif, sehingga pencucian perlu lebih ditingkatkan sampai netral agar dapat mengeliminasi pengotor berupa warna dan hasil sampingan yang terbentuk.

\section{Penampakan, warna, dan derajat putih Glukosamin Hidroklorida (GlcN HCl)}

Kriteria penampakan glukosamin terbaik dilihat dari tekstur glukosamin setelah dikeringkan dan dihaluskan. Penampakan dinilai baik jika sampel berbentuk serbuk halus setelah penghalusan. Warna dan derajat putih glukosamin dianggap baik jika sesuai atau mendekati warna dan derajat putih glukosamin standar (Gambar $1 \mathrm{c}$ ).

Parameter visual yang meliputi penampakan, warna, dan derajat putih glukosamin hidrolisis sudah sesuai dengan glukosamin standar. Glukosamin yang dihasilkan memiliki tekstur serbuk berukuran sekitar 60 mesh. Glukosamin yang dibuat dari kitosan sangat mudah dihaluskan, hal ini diduga dapat terjadi karena ikatan monomer pada kitosan telah terurai sempurna selama proses hidrolisis menjadi glukosamin. Kitosan telah terurai menjadi molekul-molekul glukosamin yang lebih pendek dan bersifat polar (terdapat gugus $\mathrm{O}-\mathrm{H}$ ) sehingga larut baik dalam air.

Molekul yang memiliki banyak gugus polar mudah dilarutkan dalam air. Gugus hidroksil O-H yang terikat pada atom karbon suatu molekul merupakan tapak untuk interaksi dwikutub dengan molekul air. Tarikan ini menggantikan interaksi zat-zat terlarut sehingga setiap molekul glukosamin yang digabungkan dengan air akan terlarut menjadi larutan.

\section{Loss on Drying (LoD)}

Uji pengurangan bobot didesain untuk mengukur jumlah air dan komponen volatil yang mungkin masih terkandung dalam sampel ketika dikeringkan pada kondisi tertentu. Glukosamin dengan bobot tertentu dipanaskan dalam oven pada suhu $105{ }^{\circ} \mathrm{C}$ selama 2 jam. Uji LoD pada penelitian ini dilakukan secara duplo. Sesuai dengan kriteria mutu USP, nilai LoD glukosamin hidroklorida tidak lebih dari 1\% (Tabel 2). Rata-rata hasil uji menunjukkan bahwa nilai pengurangan bobot glukosamin setelah pemanasan $105^{\circ} \mathrm{C}$ selama 2 jam tidak lebih dari $1 \%$ yakni hanya mencapai $0.92 \%$. Nilai LoD ini telah sesuai dengan standar yang disyaratkan oleh USP.

\section{Rendemen Glukosamin Hidroklorida (GlcN HC1)}

Nilai rendemen dihitung dengan membandingkan jumlah bobot sampel akhir dengan sampel awal kitosan. Rendemen terbesar glukosamin dengan warna dan penampakan terbaik dihasilkan pada perlakuan asam 8\% yakni $69.80 \%$. Nilai rendemen glukosamin pada penelitian ini lebih besar jika dibandingkan dengan nilai rendemen Rismawan (2012) yang hanya mencapai $51.04 \%$ dengan penggunaan asam lebih pekat.

Perbedaan nilai rendemen glukosamin ini diduga dipengaruhi oleh faktor suhu, konsentrasi asam, waktu pemanasan, dan tekanan yang diberikan. Mojarrad et al. (2007) menyatakan bahwa perbandingan antara waktu hidrolisis dan konsentrasi asam merupakan faktor yang menentukan nilai rendemen glukosamin. Nilai rendemen GlcN yang dihasilkan menurun seiring dengan peningkatan konsentrasi asam dan waktu reaksi (Tabel 3). Penurunan rendemen diduga terjadi karena adanya reaksi yang belum optimum sehingga sebagian kitosan belum menjadi glukosamin atau adanya reaksi samping yang terbentuk dari zat pengotor yang dapat menurunkan nilai rendemen GlcN yang dihasilkan (Gambar 2).

Afridiana (2011) dan Rismawan (2012) berturut-turut menggunakan $\mathrm{HCl}$ dengan konsentrasi 37\% dan 22\% (v/v) untuk memperoleh glukosamin dengan karakteristik terbaik. Akan tetapi, pada penelitian ini konsentrasi asam 8\% telah mampu menghidrolisis glukosamin dengan karakter yang cukup baik. Hal ini terjadi karena adanya faktor tekanan yang diberikan saat hidrolisis. Kombinasi perlakuan antara tekanan dan suhu mempercepat proses depolimerisasi kitosan menjadi glukosamin sehingga waktu pemanasan menjadi lebih singkat dengan konsentrasi asam yang cukup rendah.

\section{Titik leleh Glukosamin Hidroklorida (GlcN HCl)}

Hasil analisis Mel Temp menunjukkan bahwa titik leleh GlcN berkisar pada 190-193 ${ }^{\circ} \mathrm{C}$ (Tabel 3). Hal ini menunjukkan bahwa 
GlcN yang dihasilkan lebih bersih. Semakin banyak pengotor atau zat asing yang terkandung dalam glukosamin maka titik leleh akan semakin menurun, kisaran nilai titik leleh glukosamin hidrolisis (Gambar 3) sesuai dengan penelitian Kralovec dan Barrow (2008) yakni 190-194 ${ }^{\circ} \mathrm{C}$. Titik leleh GlcN yang dihasilkan juga lebih baik dari penelitian pembanding yang berkisar antara $187-189{ }^{\circ} \mathrm{C}$ pada penggunaan asam (37\%). Mojarrad et al. (2007) membuat glukosamin hidroklorida (Gambar 3) dengan titik leleh $190-192{ }^{\circ} \mathrm{C}$ pada penggunaan konsentrasi asam $32 \%$.

\section{Spektrum Glukosamin Hidroklorida (GlcN HCl)}

Hasil pengukuran spektrum FTIR menunjukkan bahwa spektrum GlcN $\mathrm{HCl}$ pembanding (Gambar 5) memperlihatkan gugus $\mathrm{O}-\mathrm{H}$ yang dominan dengan garis lebar dan kuat pada bilangan gelombang $3066 \mathrm{~cm}-1$, sedangkan pada GlcN $\mathrm{HCl}$ hasil hidrolisis bertekanan (Gambar 4) menunjukkan gugus $\mathrm{O}-\mathrm{H}$ yang dominan pada bilangan gelombang 3000-3263 $\mathrm{cm}^{-1}$. Brugnerotto (2001) menambahkan bahw $\mathrm{GlcN} \mathrm{HCl}$ akan menunjukkan gugus $\mathrm{O}-\mathrm{H}$ pada bilangan gelombang $3350 \mathrm{~cm}^{-1}$ sedangkan jika sampel berbentuk polimer maka gugus $\mathrm{O}-\mathrm{H}$ semakin mendekati 3450 $\mathrm{cm}-1$ Gugus amina $\mathrm{N}-\mathrm{H}$ pada glukosamin hasil hidrolisis adalah $3333 \mathrm{~cm}^{-1}$, mirip dengan hasil Mojarrad et al. (2007) yaitu $3333-3380 \mathrm{~cm}^{-1}$. Pita serapan gugus $\mathrm{N}-\mathrm{H}$ amida primer ditunjukkan pada $1635 \mathrm{~cm}^{-1}$ sedangkan pita serapan amida sekunder berada pada $1566 \mathrm{~cm}^{-1}$. Pita serapan ini mirip dengan hasil penelitian Mojarradet et al. (2007) yakni $1535-1583 \mathrm{~cm}^{-1}$.

Pita serapan gugus khas pada GlcN hasil hidrolisis secara keseluruhan menunjukkan kesesuaian dengan GlcN $\mathrm{HCl}$ standar dan hasil penelitian lainnya,
Terdapat selisih/perbedaan nilai serapan tapi masih dalam rentang standar, hal ini terjadi justru karena perbadaan kemurnian hasil di mana serapan pengotor dapat mengganggu nilai serapan gelombang setiap gugus fungsi. Perbedaan serapan gelombang pada standar dan sampel dianggap normal apabila bilangan gelombang yang diserap sampel masih berada dalam kisaran bilangan gelombang gugus fungsi standar.

\section{Keunggulan pembuatan GlcN $\mathrm{HCl}$ dengan autoklaf}

Produksi GlcN $\mathrm{HCl}$ dengan metode autoklaf memiliki beberapa keunggulan dari segi keamanan, proses produksi, waktu, dan biaya produksi. Sampel tidak memerlukan proses pengadukan langsung cukup dimasukkan ke dalam Erlenmeyer kemudian ditutup dengan alufoil kemudian dimasukkan ke dalam autoklaf, dan diatur pada tekanan maksimum 1 atm selama selang waktu tertentu. Cara ini mudah dan lebih aman dilakukan jika dibandingkan dengan proses pengadukan secara langsung. Pembuatan GlcN $\mathrm{HCl}$ dengan cara pemanasan langsung, menggunakan asam pekat $30 \%$ - $80 \%$ dan memerlukan proses pengadukan kontinu dengan waktu pemanasan selama 4 jam, sedangkan pembuatan GlcN dengan autoklaf memerlukan waktu lebih singkat yakni 1 jam. Pembuatan GlcN dengan metode hidrolisis bertekanan dalam autoklaf, menggunakan asam encer sehingga menjadi lebih efisien karena perlakuan terbaik dapat diperoleh menggunakan bahan kimia teknis $(\mathrm{HCl}$ dan Isoprohyl Alcohol) pada konsentrasi rendah yakni $8 \%$, diperlukan pencucian (netralisasi) yang lebih irit. Pembuatan glukosamin hidroklorida dengan metode autoklaf dapat diproduksi dalam jumlah yang besar (scale up) dengan mudah.

Tabel 1. Karakteristik glukosamin dari kitosan pada perlakuan asam yang berbeda

\begin{tabular}{|c|c|c|c|c|c|c|}
\hline \multirow{2}{*}{$\mathrm{HCl}(\%)$} & \multirow{2}{*}{ Penampakan } & \multirow{2}{*}{ Warna } & \multirow{2}{*}{$\begin{array}{l}\text { Derajat } \\
\text { putih }\end{array}$} & \multirow{2}{*}{ Kelarutan } & \multicolumn{2}{|c|}{ Rendemen } \\
\hline & & & & & gram & $\%$ \\
\hline 0 & Serpihan & & ++ & Tidak & 2.50 & 100 \\
\hline 2 & Butiran kasar & $\begin{array}{l}\text { Kekuningan } \\
\text { Coklat jernih }\end{array}$ & ++ & $\begin{array}{l}\text { Larut } \\
\text { Larut }\end{array}$ & 2.34 & 93.80 \\
\hline 4 & Butiran kasar & Hitam & + & Larut & 2.05 & 82.00 \\
\hline 6 & Serbuk & Kecoklatan & +++ & Larut & 2.02 & 80.92 \\
\hline 8 & Serbuk & $\begin{array}{l}\text { Putih } \\
\text { Kekuningan }\end{array}$ & ++++ & Larut & 1.74 & 69.80 \\
\hline
\end{tabular}


Tabel 1 (lanjutan)

\begin{tabular}{|c|c|c|c|c|c|c|}
\hline \multirow{2}{*}{$\mathrm{HCl}(\%)$} & \multirow{2}{*}{ Penampakan } & \multirow{2}{*}{ Warna } & \multirow{2}{*}{$\begin{array}{c}\text { Derajat } \\
\text { putih }\end{array}$} & \multirow{2}{*}{ Kelarutan } & \multicolumn{2}{|c|}{ Rendemen } \\
\hline & & & & & gram & $\%$ \\
\hline 10 & Serbuk & Abu kecoklatan & +++ & Larut & 1.83 & 73.20 \\
\hline 12 & Serbuk & Abu kecoklatan & +++ & Larut & 1.52 & 60.80 \\
\hline 14 & Serbuk & Putih keabuan & ++++ & Larut & 1.42 & 56.80 \\
\hline 16 & Serbuk & Putih keabuan & ++++ & Larut & 1.26 & 50.40 \\
\hline 18 & Serbuk & Hitam & + & Larut & 1.21 & 48.56 \\
\hline 20 & Serbuk & Hitam & + & Larut & 1.23 & 49.44 \\
\hline 22 & Serbuk & Hitam & + & Larut & 1.30 & 51.88 \\
\hline
\end{tabular}

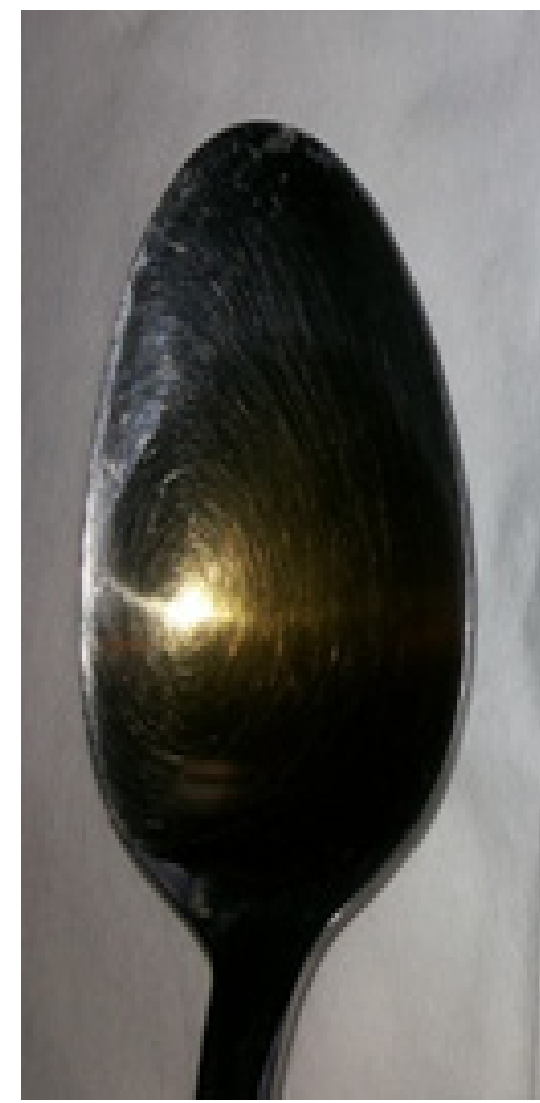

(a)

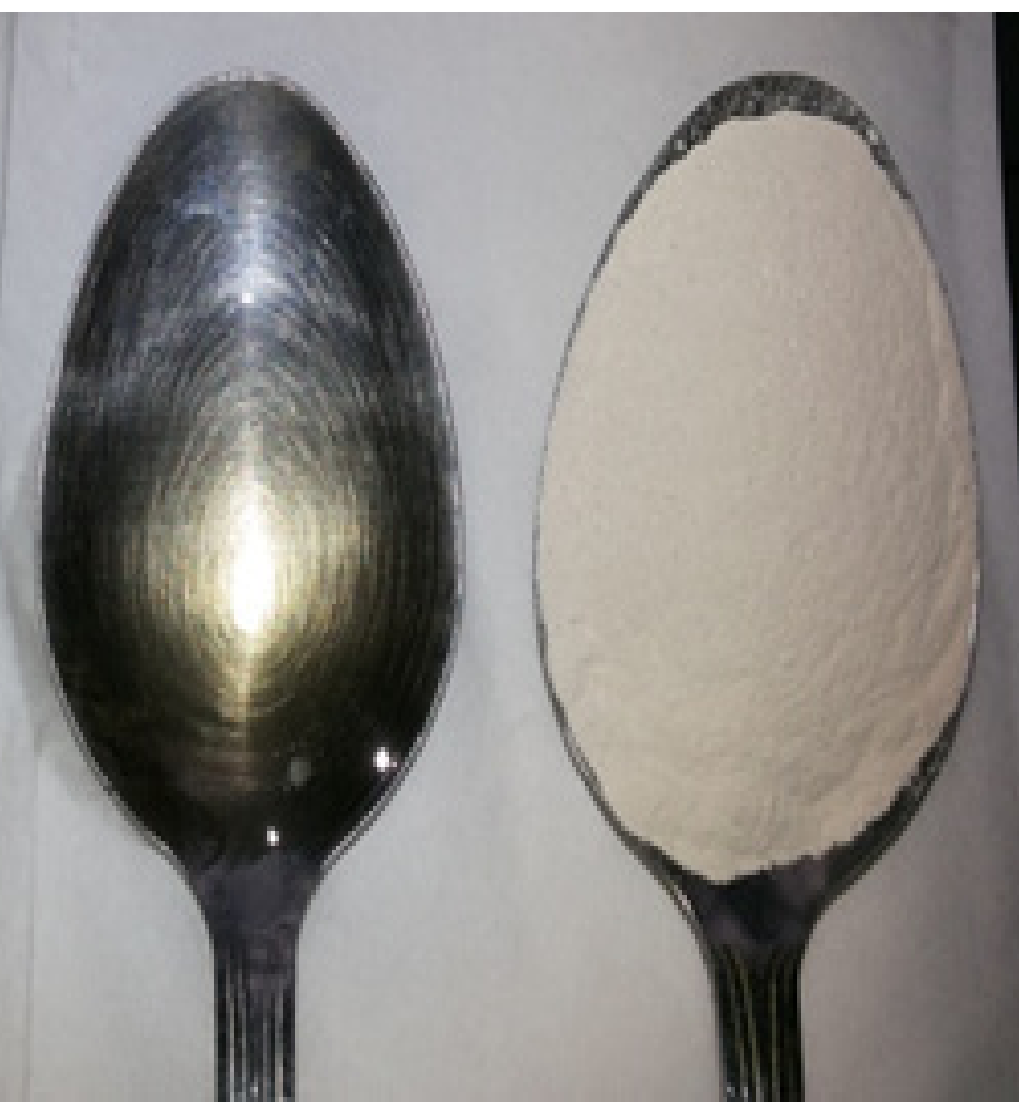

(b) (c)

Gambar 1. Glukosamin terbaik ( $\mathrm{HCl} 8 \%$ ) setelah dilarutkan (a) 2\%, (b) $1 \%$, (c) puder

Tabel 2. Pengurangan bobot glukosamin hidroklorida setelah pemanasan

\begin{tabular}{cccc}
\hline Cawan & Bobot GlcN awal $(\mathrm{g})$ & Bobot GlcN akhir $(\mathrm{g})$ & LoD $(\%)$ \\
\hline 1 & 0.3 & 0.27 & 1 \\
2 & 0.3 & 0.275 & 0.83 \\
\hline Rata-rata & 0.92 & Hitam & + \\
\hline
\end{tabular}


Tabel 3. Kisaran suhu titik leleh glukosamin hidroklorida

\begin{tabular}{cc}
\hline Tabung kapiler & Kisaran suhu $\left({ }^{\circ} \mathrm{C}\right)$ \\
\hline 1 & $190-192$ \\
2 & $190-192$ \\
3 & $191-193$ \\
\hline Rata-rata & 191.3 \\
\hline
\end{tabular}

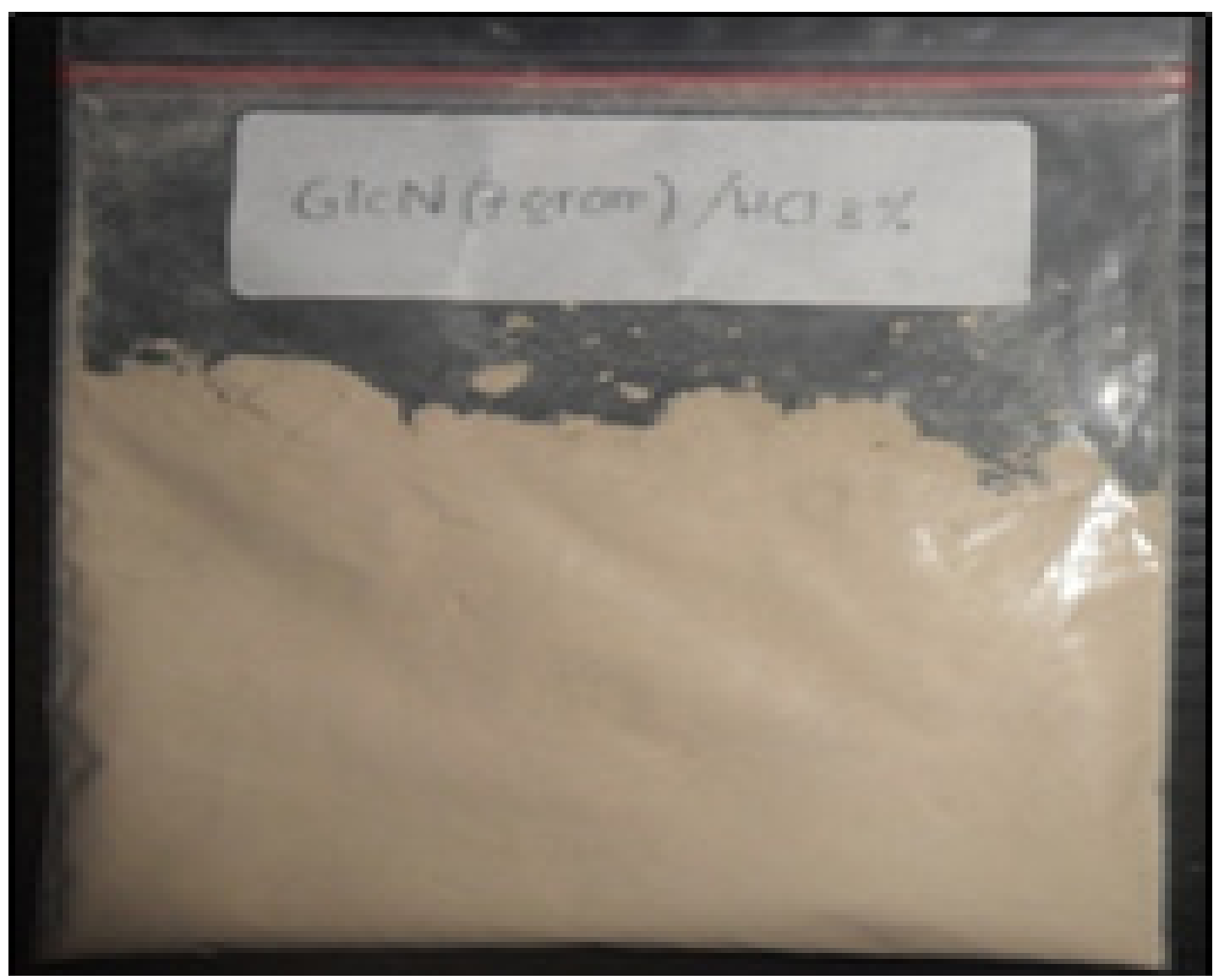

Gambar 3. Penampakan glukosamin hidroklorida 


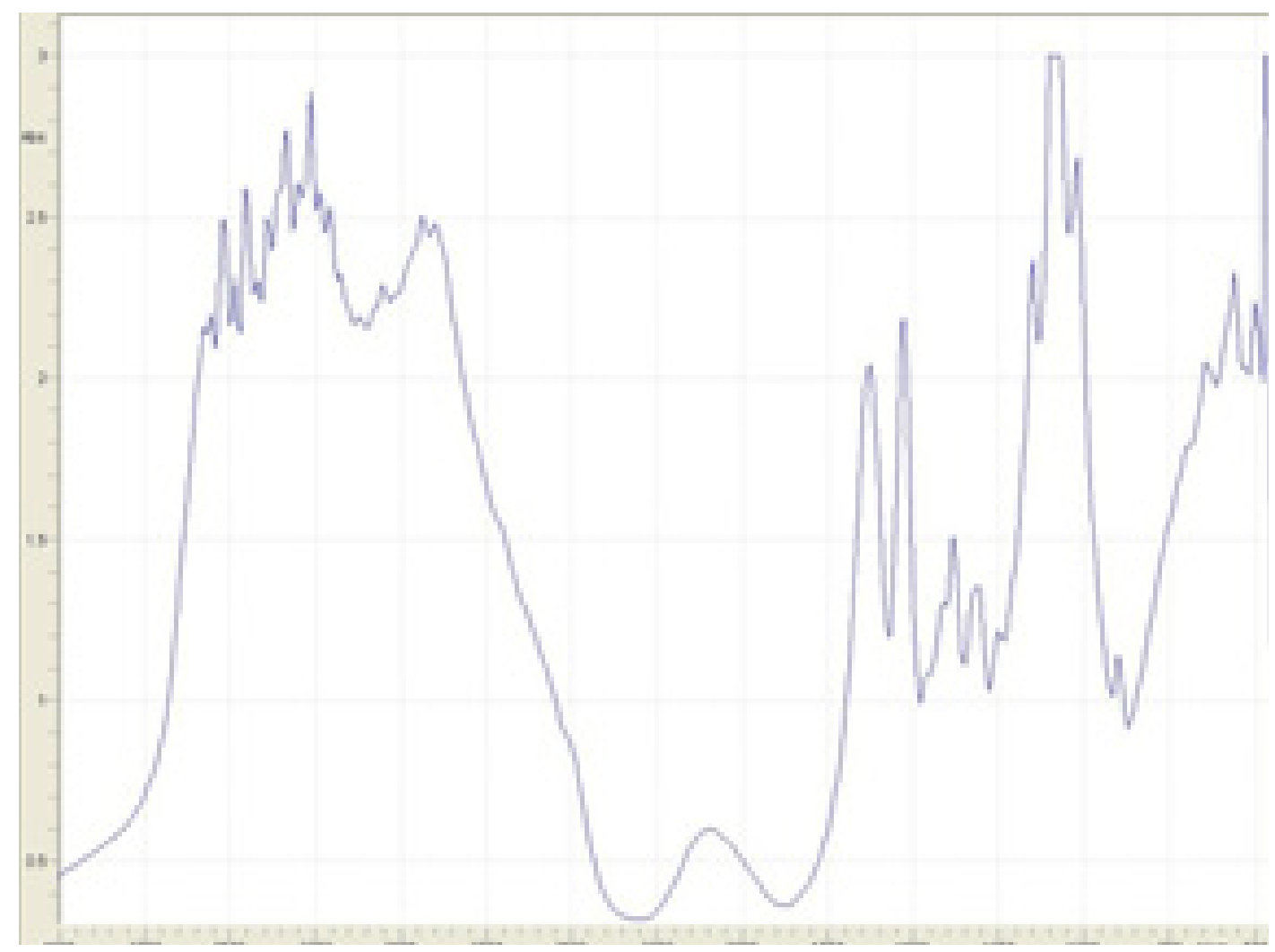

Gambar 4. Spektrum FTIR GlcN HCl hasil hidrolisis $\mathrm{HCl} 8 \%\left(450-4000 \mathrm{~cm}^{-1}\right)$

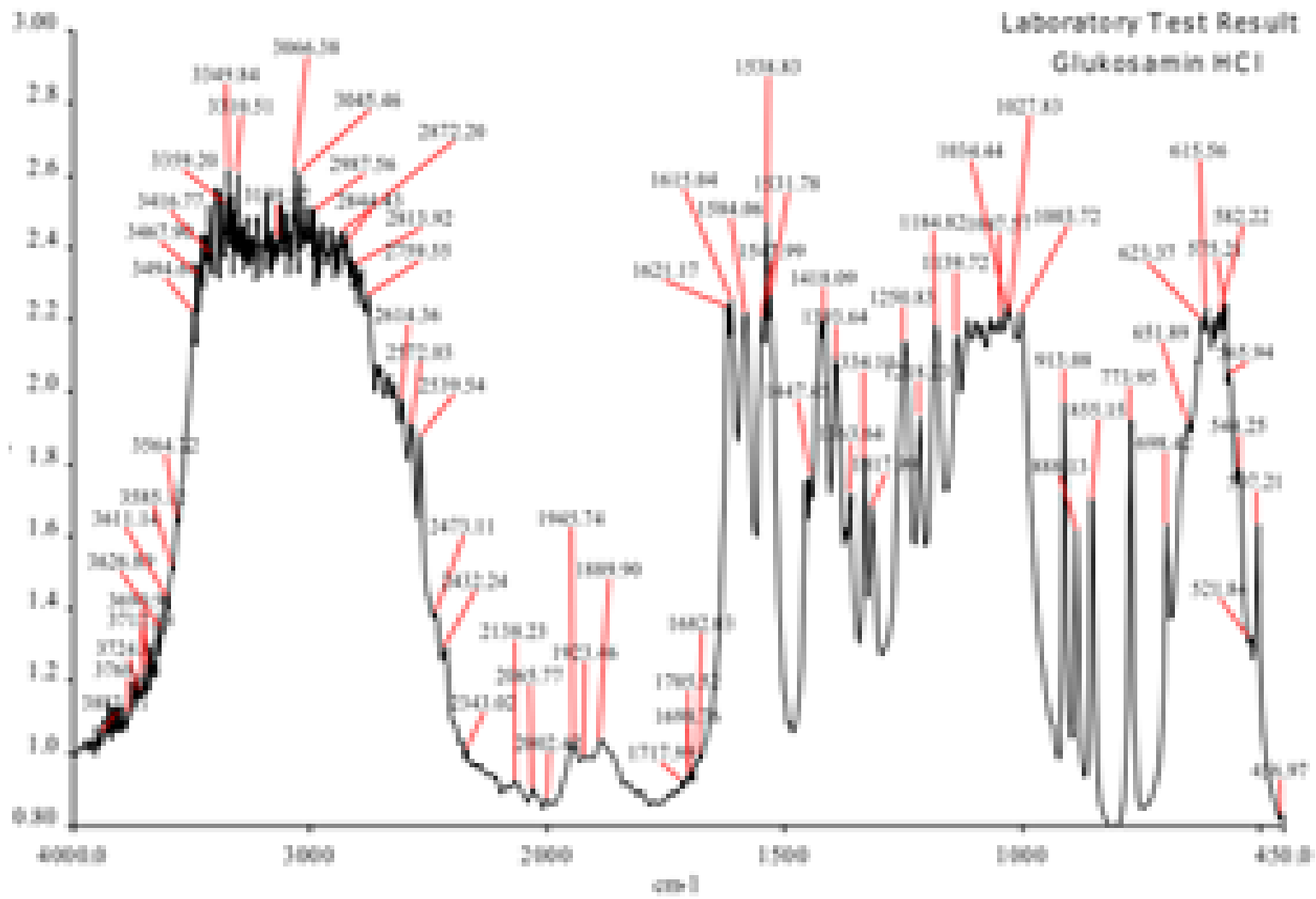

Gambar 5. Spektrum FTIR GlcN HCl pembanding (Afridiana 2011) 


\section{KESIMPULAN DAN SARAN}

\section{Kesimpulan}

Glukosamin hidroklorida (GlcN $\mathrm{HCl})$ dapat dibuat dengan teknik hidrolisis bertekanan yakni dengan penggunaan autoklaf. Pembuatan $\mathrm{GlcN} \mathrm{HCl}$ dengan metode autoklaf lebih unggul dari segi keamanan kerja, proses produksi, waktu, dan biaya produksi. Perlakuan terbaik GlcN diperoleh pada penggunaan asam $8 \%$ dengan tekanan 1 atm selama 1 jam. GlcN $\mathrm{HCl}$ hasil hidrolisis memiliki beberapa karakteristik yakni larut sempurna dalam air, berbentuk serbuk berwarna putih kekuningan, nilai LoD (0.92\%), titik leleh 190-192 ${ }^{\circ} \mathrm{C}$, rendemen $(69.80 \%)$, dan memiliki pola pita serapan FTIR yang mirip dengan GlcN $\mathrm{HCl}$ standar.

\section{Saran}

Jika masyarakat ingin memanfaatkan dan mengelola sumber daya kelautan dan perikanan, maka perlu diperhatikan daya dukung lingkungan perairan agar tidak mengurangikan daya dukung lingkungan terhadap kegiatan budidaya di Perairan Pulau Semak Daun berdasarkan penghitungan beban limbah $\mathrm{N}$.

\section{DAFTAR PUSTAKA}

Afridiana N. 2011. Recovery glukosamin hidroklorida dari cangkang udang melalui hidrolisis kimiawi sebagai bahan sediaan suplemen osteoartritis [Skripsi]. Bogor: Institut Pertanian Bogor.

Azhar M, Efendi J, Syofyeni E, Lesi RM, Novalina S. 2010. Pengaruh konsentrasi $\mathrm{NaOH}$ dan $\mathrm{KOH}$ terhadap derajat deasetilasi kitin dari limbah kulit udang. Eksakta. VOL 1:1-8.

Kralovec JA, Barrow JC. 2008. Marine Neutraceticals and Functional Foods. London. New York: CRC Press.

Brugnerotto J. 2001. An infrared investigation inrealtion with chitin and chitosan characterization. Polymer. Vol 42: 3569-3580.

Cibere J, Kopec JA, Thorne A, Singer J, Canvin J, Robinson DB, Pope J, Hong P, Grant E, Esdaile JM. 2004. Randomized, double-blind, placebo-controlled glucosamine discontinuation trial in knee osteoarthritis. Journal of Arthritis and Rheumatism. VOL 51: 738-745.

Clegg RDJ, Harris CL, Klein MA, O’Dell JR, Hooper MM, Bradley JD, Bingham CO, Weisman MH, Jackson CG, Lane NE et al. 2006. Glucosamine, chondroitin sulfate, and the two in combination for painful knee osteoarthritis. New England Journal of Medicine. VOL 354: 795-808.

[EFSA] European Food Safety Authority. 2009. Scientific opinion on the substantiation of a health claim related to glucosamine hydrochloride and reduced rate of cartilage degeneration and reduced risk of development of osteoarthritis pursuant. European Food Safety Authority. VOL 7(10): 1358.

Kulkarni C, Leena A, Lohit K, Mishra D, Saji MJ. 2012. A randomized comparative study of safety and efficacy between immediate release glucosamine $\mathrm{HCL}$ and glucosamine HCL sustained release formulation in the treatment of knee osteoarthritis: A proof of concept study. Journal of Pharmacology and Pharmacotherapeutics. VOL 1:1-10.

Mojarrad JS, Mahboob N, Valizadeh H, Ansarin M, Bourbour S. 2007. Preparation of glucosamine from exoskeleton of shrimp and predicting production by response surface metodhology. Journal of Agricultural and Chemistry. VOL 55:2246-2250.

Mustamin, Manjang S. 2010. Karakterisasi isolator polimer tegangan tinggi di bawah penuaan tekanan iklim tropis buatan yang dipercepat. Media Elektrik. VOL 5 (2): 2.

Rismawan. 2012. Rendemen glukosamin dari kitin udang [Skripsi]. Bogor : Institut Pertanian Bogor

Usha PR, Naidu MUR. 2004. Randomised, double-blind, parallel, placebocontrolled study of oral glucosamine, methylsulfonylmethane and their combination in osteoarthritis. Clinical Drug Investigation. VOL 24: 353-363.

Wang SX, Laverty S, Dimitriu M, Plaas A, Grynpas MD. 2007. The effects of glucosamine hydrochloride onsubchondral bone changes in ananimal model of osteoarthritis. Journal of Arthritis and Rheumatism VOL (5): 1537-1548.

White T, Stegemann JA. 2001. Environmentally preferred materials. Advance in Environmental Materials. Material Research Society: Singapore2: 